\title{
pÿThe Why Question in International Criminal Punishment \\ Framing the Landscapes of Asking
}

\section{Tallgren, Immi}

Cambridge University Press

2020-02

pÿTallgren , I 2020 , The Why Question in International Criminal Punishment Framing the Landscapes of Asking . in F Jessberger \& J Geneuss (eds), Why Punish Perpetrators of Mass Atrocities? : Purposes of Punishment in International Criminal Law . ASIL Studies in International Legal Theory , Cambridge University Press , pp. 113-128 . https://doi.org/10.1017/9781108566360.009

http://hdl.handle.net/10138/326863

https://doi.org/10.1017/9781108566360.009

unspecified

publishedVersion

Downloaded from Helda, University of Helsinki institutional repository.

This is an electronic reprint of the original article.

This reprint may differ from the original in pagination and typographic detail.

Please cite the original version. 


\section{The Why Question in International Criminal Punishment - Framing the Landscapes of Asking}

\author{
A Comment on the Contributions by Frank Neubacher, \\ Sergey Vasiliev and Elies van Sliedregt
}

\author{
IMMI TALLGREN
}

Setting the framework for the discussions "with criminological, historical and domestic perspectives" is the task in the first part of this volume Why Punish Perpetrators of Mass Atrocities? Purposes of Punishment in International Criminal Law. As the chapters and the symposium that preceded them demonstrate, however, there is no clear framework in which to ask such a question. In particular, it is difficult if not impossible to separate the question of why punish from other questions related to understanding and explaining mass atrocities: what mass atrocities are considered to consist of, who are to be understood as their perpetrators (in simplified terms: the boots on the ground or the Bembas and Gbagbos), how they are committed and why, for what causes and by which processes. What is even more challenging, as it became clear, is to treat the why punish question as a separate issue from describing one's disciplinary or personal preferences for dealing with mass atrocities in general. How should perpetrators of mass atrocities be punished and by whom? How should victims be dealt with? What kinds of institutions are needed (if any)?

The differences in approaching the why question could be discussed in terms of academic disciplines and expert knowledge. One could talk of 'epistemic communities' of international lawyers, international criminal lawyers, criminal lawyers, criminologists or international-relations scholars, to mention a few. ${ }^{2}$ One could refer to the fragmentation of law and policies,

\footnotetext{
I would like to thank warmly the organizers of the Hamburg symposium, Florian Jeßberger and Julia Geneuss, and its participants for stimulating discussions. Frédéric Mégret, Parvathi

Menon, Sergey Vasiliev and Matthew Windsor provided astute comments on my draft, thank you again.

1 See the table of contents of this volume.

2 See e.g., P.M. Haas, 'Introduction: Epistemic Communities and International Policy

Coordination' (1992) 46 International Organization 1; A. Bianchi, 'Epistemic Communities' in
} 
or of professional expertise. Such talk does not go deep enough, however. The question why punish? evokes personal positions and convictions that fail to find an explanation merely with reference to one's academic education or belonging to a specific professional community.

Framing, frame and framework are code words used in social sciences and media studies, as well as in political science, psychology and economics, denoting a set of concepts and perspectives of inquiry into the processes of thought, interpersonal communication, and decision-making. Erving Goffman, the key reference here, suggests that framing reality takes place in order to 'negotiate it, manage it, comprehend it and choose appropriate repertories of cognition and action'.3 Framing, as Robert Entman argues, certainly is a 'scattered conceptualization', a 'potential research paradigm that remains fractured', and it is 'often defined casually, with much left to an assumed tacit understanding of reader and researcher. ${ }^{4}$ I will not attempt an explicit definition here, either. Entman's description of what frames do is sufficiently helpful:

Frames define problems - determine what a causal agent is doing with what costs and benefits, usually measured in terms of common cultural values; diagnose causes - identify the forces creating the problem; make moral judgements - evaluate the causal agents and their effects; and suggest remedies - offer and justify treatments for the problems and predict their likely effects. ${ }^{5}$

Framing has further meanings and dimensions beyond the disciplines mentioned above. Discussing the representation of atrocity, Susan Sontag points out that 'to photograph is to frame, and to frame is to exclude'. 6 The frame for a filmmaker, however, in contrast to a photographer or a painter, is not fixed but is rather a choice of movement, which at times results in the powerful inclusion of what is taking place outside the frame. It suffices to think of Michelangelo Antonioni or Michael Haneke, whose use of hors-champ underlines how what is shown in the frame is not what 'really happens': the spectator senses that what counts most is not visible. ${ }^{7}$

J. d'Aspremont and S. Singh (eds.), Concepts for International Law (Cheltenham: Edward Elgar, 2019).

3 E. Goffman, Frame Analysis: An Essay on the Organization of Experience (Boston:

Northeastern University Press, 1986).

4 R.M. Entman, 'Framing: Toward Clarification of a Fractured Paradigm' (1993) 43 Journal of Communication $51,51-52$.

5 Entman, 'Framing', 52 (emphasis in the original).

6 S. Sontag, Regarding the Pain of Others (New York: Picador/Farrar, Straus and Giroux, 2003), 46 .

7 See, e.g., Antonioni, Blow-Up, 1966; Haneke, Funny Games, 1997. 
In the following, I set out the why punish question in a few frames that inform the question as it is raised in this volume. Some of them are explicitly evoked, others are implicitly present. I am not suggesting that these frames are the only ones, or that they are necessarily distinct from each other in all respects. The idea is simply to picture the landscape in which the why question is asked, and thereby to shed light on the contexts of that context of knowledge, its production, reproduction and subjectivities. By drawing attention to the plurality of perspectives that could be taken on punishment at the outset of this very welcome volume, I wish to challenge the discursive hegemonies on international criminal punishment. Whatever effort is undertaken to set the framework, be it in the contributions in this volume or elsewhere, it remains a contingent exercize that inevitably has an outside, whether or not we choose to make it visible.

\section{THE LANDSCAPES OF WHY}

Criminal law and its institutional practice in international, hybrid and national tribunals became the main field of reference for naming and conceptualizing the phenomenon of mass atrocities and coping with it in a rapid turn that started in the early 1990s. The international criminal justice project ${ }^{8}$ grew into what Sergey Vasiliev refers to as 'a grandiose industry holding a considerable symbolic and political leverage and distinguished by a sophisticated institutional culture $[\ldots]$ and practices and routines'. ${ }^{9}$ The turn to criminal justice pushed into the background other discourses and policies such as democracy-building, international human rights with their supervisory mechanisms, international development and much of the discussion on humanitarian intervention with the legal and political analyzes of the use of force. To some extent, the absence of interventions in situations in which mass atrocities continued to be committed was perceived differently now that there was (criminal) justice to follow, sooner or later. The turn to criminal law was accompanied by efforts to explain mass atrocity as crime using language, models and structures commonly adopted to refer to deviance within a society. As a result of these efforts, the discipline of criminology entered the scene, as did various other genres of social sciences concerned with behaviour, either individual or collective: sociology, socio-psychology, psychology, psychiatry

8 The term as used here encompasses both international criminal law and the courts and tribunals involved in its institutional practice, as well as the political activity and advocacy related to international criminal responsibility in general.

9 See the contribution by Sergey Vasiliev in Chapter 4 (p. 45). 
and anthropology, for example. The first frame I address is the one of approaching the why question with the expertise and vocabulary that emanates from law, followed by those emanating from criminology, morality, 'fantasmatic logic' (explained in Section I.4) and politics.

\section{The Frame of Law}

Why punish? Because the law says we must. This straightforward answer consists of steps in a sequence, from why investigate, why prosecute and why convict to why punish. The legal frame at its simplest reflects the domestic analogy of criminal justice, mirroring the (idealized) situation of a state in which there exists a comprehensive criminal code and adequate rules covering investigation, prosecution, trial and punishment in cases of mass atrocity, as well as competent authorities and independent courts with the resources to apply the law. ${ }^{10}$ Within such a national legal system, mere information about the alleged commission of a criminal act should lead at least to a criminal investigation, with subsequent steps taken in accordance with the law and the decisions of judicial actors. Complementing domestic legal provisions is a broader net of systems in cases of certain types of mass atrocity (and other types of international crimes), including international agreements that oblige the state parties involved either to prosecute or to extradite. Finally, there are international jurisdictions with their own legal rules, most notably the International Criminal Court (ICC). In addition, parts of the material criminal law on mass atrocities could also be in force as customary international law, and ius cogens, as rich doctrinal discussions in the frame of law demonstrate.

Such an image of lawyers occupied with only their rules, safe in the confines of the legal system(s), distanced from the muddled social and political circumstances that, observed from the legal frame, belong to the past preceding the birth moments of the law, is of course a caricature. Yet with regard to mass atrocities, the legal frame nowadays appears to be over-invested. In stark contrast to the lack of criminological, sociological or political sciences research on international crimes until very recent times, research programmes and libraries have burst with legal analyzes of international criminal law and its institutional practice. Discussion on the legal why or why not in the context of current or recent international judicial institutions has focused on the dogmatic analysis of jurisdiction, complementarity or prosecutorial discretion, in light of the existing norms in force.

${ }^{10}$ On the domestic analogy, see the contribution by Elies van Sliedregt in Chapter 5. 


\section{The Frame of Criminology}

Expressed in simplified terms, this frame approaches the problems relating to crimes and their control and suggests remedies based on beliefs about individual or collective human behaviour in communities and societies. The word beliefs carries no pejorative sense but refers to current knowledge in the social sciences, much of which is based on empirical research. As is known - and we are reminded of this by Frank Neubacher's reference to Cesare Beccaria ${ }^{11}$ such beliefs as well as the methodologies of empirical research have changed over time and will most likely continue evolving. The preoccupations of criminology as a field of study, typically in national contexts, include the causes of crime; the objectives, opportunities, costs and risks associated with crime control; and efforts to understand the conditions in which a person, an entity or a collective transgresses, as well as how systems of crime control and punishment affect individuals and entities.

As the editors of this volume and other commentators note, criminological analysis of mass atrocities is scarce. ${ }^{12}$ Even if more interventions have been published recently, the key outcome remains a call for more research or more adequate research. ${ }^{13}$ The analysis of mass atrocities as international crimes remains absent from textbooks of criminology, both in classics such as Criminology ${ }^{14}$ and in more recent works such as the Oxford Handbook of Criminology - the fifth edition (2012) finally contains a chapter at least on State Crime. ${ }^{15}$ Why would this be the case? The reluctance to deal with genocide and other mass atrocities is often attributed to the relationship between criminology and the state. The role of modern political states as pursuers of final solutions in their vastness and totality, with access to resources, administrative capacities and law-making competence, makes the

${ }^{11}$ See the contribution by Frank Neubacher in Chapter 3 referring to Beccaria's statement in ${ }_{17} 64$ (p. 43).

${ }_{12}$ See the Introduction by the editors; S. Parmentier, "The Missing Link: Criminological Perspectives on Transnational Justice and International Crimes' in M. Bosworth and C. Hoyle (eds.), What is Criminology? (Oxford: Oxford University Press, 2011), 380; S. Harrendorf, 'How Can Criminology Contribute to an Explanation of International Crimes' (2014) 12 Journal of International Criminal Justice 231.

13 See, e.g., C.W. Mullins and D.L. Rothe, "The Ability of the International Criminal Court to Deter Violations of International Criminal Law' (2010) 10 International Criminal Law Review 771; A. Smeulers and R. Haveman (eds.), Supranational Criminology: Towards a Criminology of International Crimes (Antwerp: Intersentia Press, 2008).

${ }^{14}$ E.H. Sutherland and D.R. Cressey, Criminology, 1oth ed. (Philadelphia: Lippincott, 1978).

15 M. Maguire, R. Morgan and R. Reiner, Oxford Handbook of Criminology (Oxford: Oxford University Press, 2012). 
basic criminological paradigm appear too reductive. ${ }^{16}$ As Chris Cunneen writes: "[...] the positivist approaches in law and criminology [that] define "crime" as a breach of state criminal law, and count crimes from the data driven by state agencies. Within such state-centric discourses, it is difficult to conceptualize the incidence and nature of state crime. ${ }^{17}$ Criminologists and other social scientists in this frame may feel more at ease remaining within the confines of a state-enclosed paradigm because, as Andy Aitchison puts it, 'atrocity crimes take place in uncivilised or unpacified spaces' ${ }^{18}$ Katja Aas, as well, refers to the failure of 'territorial imagination' in a discipline limiting itself to 'pacified domestic spaces' ${ }^{19}$

At the same time, criminologists and other social scientists had a decisive role in encouraging an internationalist view' of criminality, as Paul Knepper states. He studied how, at the turn of the twentieth century, the new discipline of criminology 'transformed criminal behavior into a universal problem about which scientists, doctors, judges, professors, politicians and anyone else engaged in social criticism had an opinion'. ${ }^{20}$ Ever since, the criminologist has been involved in and contributed to analysing, explaining and at times preventing 'international crime' and thereby breathed life and meaning into the concept, often in collaboration with the national or international institutions manned with legal professionals with a mission to deal with international crime'.

How does the criminologist tackle the why question? The basic rationale behind the answers to why? in this frame is consequentialist and focused on perpetrators, the expectation being that punishment could shape the future behaviour of the criminal and others (potential perpetrators). This does not mean that every criminologist working in this frame necessarily adheres to such rationales or otherwise has the hubris to save the world from

16 See W. Morrison, Criminology, Civilisation and the New World Order (Abington: Routledge, 2006); R. Gellately and B. Kiernan (eds.), The Spectre of Genocide: Mass Murder in Historical Perspective (Cambridge: Cambridge University Press, 2010).

17 C. Cunneen, 'Postcolonial Perspectives for Criminology' in M. Bosworth and C. Hoyle (eds.), What Is Criminology? (Oxford: Oxford University Press, 2011), 249, 253.

18 A. Aitchison, 'Criminological Theory and International Crimes' in I. Bantekas and E. Mylonaki (eds.), Criminological Approaches to International Criminal Law (Cambridge: Cambridge University Press, 2014), 22, 27.

19 K. Aas, "The Earth Is One but the World Is Not: Criminological Theory and Its Geopolitical Divisions' (2012) 16 Theoretical Criminology 5, 12.

20 P. Knepper, The Invention of International Crimes. A Global Issue in the Making, 1881-1914 (Basingtoke: Palgrave Macmillan, 2009), 10. See also, N. Rafter, 'Origins of Criminology' in M. Bosworth and C. Hoyle (eds.), What Is Criminology? (Oxford: Oxford University Press, 2011), 143, 145-146. 
international crimes. Not everyone sets the goal as high as finding 'the keys to a future free of genocide', as Augustine Brannigan puts it in Beyond the Banality of Evil: Criminology and Genocide. ${ }^{21}$ Alette Smeulers and Fred Grünfeld, authors of an interdisciplinary textbook, merely 'aim to contribute to a more humane future. ${ }^{22}$ Notably, however, critical or radical criminology, which questions the power and control exercised by criminal justice with its inequalities in domestic contexts, has remained marginal if not absent in discussions on international crime. This may relate to the openly punitive ideologies dominant in international criminal justice institutions and the broader political project. As Kelly Hannah-Moffat points out in a domestic context, criminologists typically cooperate with these institutions: "[i]nstitutional research practices can produce a context wherein some forms of intellectual inquiry are seen as "legitimate" and others as "threatening" or redundant'. ${ }^{23}$ It cannot be excluded that with regard to international crime, the production of criminological knowledge is also subject to 'various forms of institutional protectionism and intellectual polarizations'. ${ }^{24}$

Criminological approaches adhering to the consequentialist rationale differ in terms of whether the focus is on the interaction between the individual perpetrator and his or her environment or, in contrast, on possible individual defects of the perpetrators. Importantly, there is a tendency to attach less importance to the social and economic context of the (potential) perpetrators of international crimes than in criminology in general. Perpetrators with the higher levels of hierarchical standing and responsibility, referred to as 'the bigger fry' by Elies van Sliedregt, ${ }^{25}$ attract stigmas of evil, bestiality, moral devastation or duplicity, which were broadly debated in earlier scholarship on Nazi criminality. Criminological discussions that accompanied the turn to international criminal law in the early 1990 s revisited the landmarks of that genre, including Hannah Arendt's account of Adolf Eichmann's trial giving birth to the trope of the obedient bureaucrat, supported by Stanley Milgram's controversial empirical studies. ${ }^{26}$ Today's frame of criminology appears to be

\footnotetext{
${ }^{21}$ A. Brannigan, Beyond the Banality of Evil: Criminology and Genocide (Oxford: Oxford University Press, 2013).

22 A. Smeulers and F. Grünfeld, International Crimes and Other Gross Human Rights Violations: A Multi- and Interdisciplinary Textbook (Leiden: Martinus Nijhoff Publishers, 2011), xiii.

${ }^{23}$ K. Hannah-Moffat, 'Criminological Cliques: Narrowing Dialogues, Institutional Protectionism, and the Next Generation' in M. Bosworth and C. Hoyle (eds.), What Is Criminology? (Oxford: Oxford University Press, 2011), 440, 445.

24 Hannah-Moffat, 'Criminological Cliques', 445.

25 See the contribution by Elies van Sliedregt in Chapter 5 (p. 94).

26 H. Arendt, Eichmann in Jerusalem: A Report on the Banality of Evil (New York: Viking Press, 1963); S. Milgram, Obedience to Authority (New York: Harper and Row, 1974).
} 
moving away from those emblematic discussions, however. As Frank Neubacher's chapter demonstrates, it tends to flag an acknowledgement of the overall complexity of criminological analyzes of mass atrocities. Branches of scholarship and expertise such as transnational criminology, international criminology and global criminology are surfacing, with new approaches such as a focus on extremely violent societies or a broader understanding of victimization by atrocity. ${ }^{27}$

A key aspect affecting the frame of criminology that the Hamburg symposium did not capture relates to the ongoing change of emphasis in the international criminal justice project. The question 'Why punish perpetrators of mass atrocities?' acquires a new critical meaning in the current climate in the sense that the punitive aspect of international institutional practice is receding, giving space for a wider understanding of international criminal trials as contributing to social justice and community-building, presumably acting for and on behalf of victims in particular. ${ }^{28}$ Criminal punishment, which is pivotal to the criminological paradigm in a domestic context, may appear an accessory if not redundant in the international sphere. ${ }^{29}$ The international governance of penal power also assumes new tasks such as developing national legal systems to match the standard set by that governance, a policy that emerged in the ICC context and is known as 'positive complementarity'. ${ }^{30}$ Criminological approaches will need to adjust to situations in which international legal discourse and institutional practice move towards a constellation that is increasingly detached from the national sovereign prerogative, acting in the name of a moral community of 'humanity', ${ }^{31}$ as discussed in the following section.

27 See, e.g., S. Karstedt, 'Contextualizing Mass Atrocity Crimes: The Dynamics of "Extremely Violent Societies"' (2012) 9 European Journal of Criminology 499; J. Hagan et al., 'Atrocity Victimization and the Costs of Economic Conflict Crimes in the Battle for Baghdad and Iraq' (2012) 9 European Journal of Criminology 481.

${ }^{28}$ For a discussion see, e.g., S. Kendall and S. Nouwen, 'Representational Practices at the International Criminal Court: The Gap between Juridified and Abstract Victimhood' (2014) 76 Law and Contemporary Problems 235.

29 See, e.g., K. Lohne, 'Penal Humanitarianism Beyond the Nation State: An Analysis of International Criminal Justice' (2019) Theoretical Criminology forthcoming.

30 J. Tillier, "The ICC Prosecutor and Positive Complementarity: Strengthening the Rule of Law?' (2013) 13 International Criminal Law Review 507; C.K. Hall, 'Developing and Implementing an Effective Positive Complementarity Prosecution Strategy' in C. Stahn and G. Sluiter (eds.), The Emerging Practice of the International Criminal Court (Leiden: Brill, 2008) 219.

${ }^{31}$ See R. Teitel, Humanity's Law (Oxford: Oxford University Press, 2012); A.A. Cançado Trindade, International Law for Humankind: Towards a New Jus Gentium (Leiden: Martinus 


\section{The Moral Frame}

In contrast to the preceding frames, here the why question is articulated neither in terms of 'Do these acts fall under the jurisdiction of the court?' nor 'Does punishment prevent crime?'. The moral frame is identifiable in two main senses. In the first, idioms that mark the frame connote retribution, just deserts, redemption, repentance and atonement. Underneath the current discourse of restorative justice, the Kantian retributive theory and the notion of radical evil, with its theological connotations, may have powerful purchase in explaining the emphasis on individual criminal responsibility in the international criminal justice project. ${ }^{32}$

In the second sense, the moral frame relates to the construction and representation of punishing power in the international criminal justice project: why punish is closely associated with the question in whose name to punish. Here, punishment is understood as emanating from a broadly shared moral outrage aroused by mass atrocities - the 'revulsion of the international community', to quote a judgment of the Special Court for Sierra Leone $(\mathrm{SCSL})^{33}$ - thereby building a (political) community of humanitarianism, united by the objective of protecting human life and the human species. To quote Anthony Duff: 'Some kinds of wrong should concern us, are properly our business, in virtue of our shared humanity with their victims (and perpetrators): for such wrongs the perpetrators must answer not just to their local communities, but to humanity. ${ }^{34}$ One of the intellectual resources of this frame is sociologist Emile Durkheim's interdisciplinary work on criminal law and punishment as a way of both establishing and safeguarding the moral core

Nijhoff, 2010). For a discussion, see I. Tallgren, "The Voice of the International: Who Is Speaking?' (2015) 13 Journal of International Criminal Justice 135.

${ }^{32}$ For a traditionalist interpretation of Kant's theory of punishment, see, e.g., J.G. Murphy, Kant: The Philosophy of Right (Macon: Mercer University Press, 1970); J.G. Murphy, 'Kant's Theory of Criminal Punishment', in J.G. Murphy, Retribution, Justice, and Therapy: Essays in the Philosophy of Law (Dordrecht: D. Reidel, 1979) 82. For a reinterpretation towards deterrence, see B.S. Byrd, 'Kant's Theory of Punishment: Deterrence in Its Threat, Retribution in Its Execution' (1989) 8 Law and Philosophy 151. For recent discussion, see, e.g., F. Mégret, “The Repentant Defendant and the Potential of International Criminal Justice' (2018) 21 Contemporary Justice Review 432.

33 SCSL, Judgment of 28 May 2008 (AC), Fofana and Kondewa (CDF), SCSL-04-14-A, para. 565.

34 A. Duff, 'Authority and Responsibility in International Criminal Law' in S. Besson and J. Tasioulas (eds.), The Philosophy of International Law (Oxford University Press, 2010) 589,601 . 
of a community by means of moral reaction to offences against a 'conscience collective'. ${ }^{35}$ Although a sociological frame could be fully justified as a distinguishable frame to address the why question, the discourses advocating criminal punishment for mass atrocities in terms of expressivism or moral communication referred to in the Hamburg symposium and also in this volume typically treat the sociological frame as a mere tacitly 'helpful' extension of the moral frame..$^{36}$

\section{The Frame of 'Fantasmatic Logic'}

Let us take a closer look at the question that constitutes the title of this volume: it is not an open question (such as 'Must perpetrators of mass atrocities be punished?') but a closed one ('Why punish them?'). ${ }^{37}$ This is a characteristic example of the dominant discourse in this specific social setting of international criminal justice that I have in mind when I term this frame that of 'fantasmatic logic', for lack of a better term. I would be tempted to call it the frame of ideology, were that word not as (in)famously used and understood in too many senses. ${ }^{38}$ What is meant here is close to Jason Glynos's and David Howarth's idea of the 'fantasmatic logic' behind political projects that helps to 'maintain existing social structures by pre-emptively absorbing dislocations, preventing them from becoming [politicised and transformed]. ${ }^{39}$ Fantasmatic logic prevents positions or issues from becoming part of the political domain, in which these meanings, articulations and identities would be instituted and potentially challenged through hegemonic struggle, contestation and resistance.

35 See, I. Tallgren, 'The Durkheimian Spell of International Criminal Justice' (2013) 71 Revue interdisciplinaire d'études juridiques - Droit en context, Dossier justice internationale pénale 157; S. Nimage, 'An International Conscience Collective? Durkheimian Analysis of International Criminal Law' (2007) 7 International Criminal Law Review 561.

${ }^{6}$ For discussion, see, e.g., R.D. Sloane, "The Expressive Capacity of International Punishment: The Limits of the National Law Analogy and the Potential of International Criminal Law' (2007) 43 Stanford Journal of International Law 39; M. Drumbl, Atrocity, Punishment, and International Law (Cambridge: Cambridge University Press, 2007).

37 Sergey Vasiliev addressed this in the symposium; see also the contribution by Sergey Vasiliev in Chapter 4 (Section I.2).

$3^{8}$ See W. Rech, 'Ideology', in J. d'Aspremont and S. Singh (eds.), Concepts for International Law (Cheltenham: Edward Elgar, 2019), 393; S. Marks, The Riddle of All Constitutions: International Law, Democracy and the Critique of Ideology (Oxford: Oxford University Press, 2000), 8.

39 J. Glynos and D. Howarth, Logics of Critical Explanation in Social and Political Theory (London: Routledge, 2007), 146. 
With regard to why punish, the depoliticizing appeal of a particular narrative is recognizable in dogmas such as of 'the fight against impunity' and 'no peace without justice'. As in the moral frame, of which this frame is a close neighbour, there is no opportunity to ask whether the international punishment, administered outside of, or in contradiction to, the political and social context of a nation-state, really leads to less crime and alleviates the suffering of victims, and whether it advances peace in this particular society. That the answers are positive is taken for granted, for that is the (ideological) premise: international criminal punishment, administered in the name of the international community/humanity, is always beneficial both to the individuals and to the societies concerned, as well as to humanity at large, regardless of the circumstances and, by extension, regardless of the objective quality of that justice, let alone its subjective quality from the perspective of those over whom it is exercised. ${ }^{\circ}$ Questioning this is sacrilege. In that sense, this frame is reminiscent of religiousness. ${ }^{41}$

Even if frames of law and 'fantasmatic logic' are addressed separately here, this is not to suggest that law is separate from the latter. It is rather that the legal frame allows for articulations in which the power of the dominating narrative is disguised below the surface, as it is already embedded in the law. As Vasiliev puts it, the framework of international criminal law imposes such rigid constraints on the degree to which judges can engage with the question of why punish that 'teleological ruminations in judgements can be no more than speech acts by which courts preach international criminal law's founding articles of faith'. ${ }^{2}$

The frame of 'fantasmatic logic' is manifest throughout the international criminal justice project, from articulations of what is regarded as punishable mass atrocity to institutional architecture and communication policies adopted by the institutions. By way of an example, one can point to the sense of ownership of international criminal law and the lack of comprehension of non-adepts of the 'fantasmatic logic', visible as clashes across the disciplinary borders and the frames addressed here. Despite the frequent calls for more criminology, which we reiterated in Hamburg, those most vested in

$4 \circ$ See M. Rauschenbach and D. Scalia, 'Les accusés du Tribunal pénal international pour l'exYougoslavie: entre désenchantement et résistance' (2018) 42 Déviance et Société 535; M.-S.

Devresse and D. Scalia, 'Hearing Tried People in International Criminal Justice: Sympathy for the Devil?' (2016) 16 International Criminal Law Review 796.

$4^{1}$ For a discussion, see I. Tallgren, 'The Faith in Humanity and International Criminal Law', in P. Amorosa, M. Garcia-Salmones and M. Koskenniemi (eds.), International Law and Religion (Oxford: Oxford University Press, 2017), 334.

$4^{2}$ See the contribution by Sergey Vasiliev in Chapter 4 (p. 48). 
international criminal law appear less keen to engage in dialogue: '[c]riminologists and criminal lawyers who are uncomfortable with this political dimension would be advised to stick to domestic justice systems'. ${ }^{43}$ The political dimension here means 'the selection of situations and of cases'. ${ }^{44}$ In William Schabas's view, '[a]ll things considered, the one-sided prosecutions at Nuremberg, governed in their choice of defendants by political rather than judicial considerations, delivered a just result. They also contributed to an accurate portrait of the historical truth'. ${ }^{45}$ Such confidence in 'just results' and 'historical truth' appears possible only when there is a strong identification with the particular politics and the actors, here the post-World War II dominant block in international relations. Similar confidence in and identification with today's institutions is demonstrated by Elies van Sliedregt's proposal to alleviate the 'reality of heterogeneity' that undermines the acceptance of sentences imposed by these international courts by means of limiting taking the court room as a podium for political speeches (within the limits of fair-trial rights); prioritize outreach activities by Residual Mechanisms, together with local authorities in telling the history of the conflict, prevent rewriting history and glorifying battlefield myths. ${ }^{46}$ Inside the frame of 'fantasmatic logic', international criminal courts are granted the standing to 'authoritatively pronounce what and how history shall be remembered', making them not solely 'a potential source and site of memory, but a powerful arbiter thereof. ${ }^{47}$ The defensiveness of the status quo is at times expressed as rejection of the performance of those intruding into the frame, such as ' $[\mathrm{t}] \mathrm{he}$ rare appearances of criminologists at the international criminal tribunals. ${ }^{4}$

\section{The Frame of Politics}

Why does the ICC punish perpetrators of mass atrocities committed in the Democratic Republic of the Congo, Libya and Uganda, but not in Syria? Even if this appears at first sight to be a question of the legal frame referred to as the first frame above, to which a pertinent reply could be swiftly produced by applying the Rome Statute, it is clear that the interpretation of the Statute

43 W.A. Schabas, 'Criminology, Accountability and International Justice' in M. Bosworth and

C. Hoyle (eds.), What Is Criminology? (Oxford: Oxford University Press, 2011), 346, 356 (emphasis added).

44 Schabas, 'Criminology, Accountability and International Justice', 356.

45 Schabas, 'Criminology, Accountability and International Justice', 356.

$4^{6}$ See the contribution by Elies van Sliedregt in Chapter 5 (p. 99 et seq.).

47 N. Henry, War and Rape: Law, Memory and Justice (London: Routledge, 2011), 130.

$4^{8}$ Schabas, 'Criminology, Accountability and International Justice', 356. 
or the UN Charter is not really the point here. The question falls in the frame of politics, recognizable in the vocabulary of power, feasibility, strategic considerations, risk analysis, diplomatic relations, collateral damage or conflict of interest, depending on the exact context. Here, responses to the why (often rather why not) question do not evoke liturgical statements on prevention or moral community; they rather point to the opportunity (or lack of) to punish in a particular situation given the cost, relevant alliances, armed conflict or risk of it and other comparable aspects. These considerations often fall under the meta-language of 'political realities', and they have a marked temporal and spatial aspect.

In this frame we can also identify underlying choices of political economy. Consider, for example, Frank Neubacher's suggestion that it is more important to fight the causes of international crimes and that 'justice also needs to be sought through $[\ldots]$ development' and that 'the perpetrator's socio-political environment' should be tackled as well. ${ }^{49}$ The problem with such well-meant remarks is that, despite the oft-heard complaints about the costs and practical difficulties of international criminal trials, the alternative of structural reform is likely to be regarded as far more expensive and difficult, and thus as unrealistic. In that sense, criminal trials are a facile solution, a reaction of relative political expedience to outbursts of violence in conflicts that are structural and long term and would require comprehensive political, economic and social change to prevent mass atrocities.

The frame of politics is at times boldly explicit, but more often remains implicit, such as when choices are made about who gets access to forums in which the why question is addressed. Twenty years after the Rome conference on the establishment of the ICC, which has been strongly criticized for the gross inequality of participation, ${ }^{50}$ 'we' in Hamburg still gathered to generate and share expertise on the why question in the complete absence of scholars and practitioners from the regions and societies that currently and most concretely face both mass atrocities and international efforts to punish them. Their only visible presence during the symposium was in a series of macrophotographs of the ICC accused projected onto a screen in the meeting room, labelled as 'big fish' or 'small fish'. The flashback to the notorious Royal Museum for Central Africa in Tervuren, close to Brussels, in which relics of

49 See the contribution by Frank Neubacher in Chapter 3 (p. 44).

${ }^{\circ}$ See, e.g., C.M. Bassiouni, 'Preface' in O. Triffterer (ed.), Commentary on the Rome Statute of the International Criminal Court (Baden-Baden: Nomos, 1999) xix; A. Buchet and I. Tallgren, 'Sur la route de Rome - Les negotiations préalables à l'adoption du Statut de la Cour pénale international' in J. Fernandez and X. Pacreau (eds.), Commentaire du Statut de Rome de la Cour Pénale Internationale (Paris: Pedone, 2012), 171, 186-187. 
Leopold II's regime in the Congo were, until recently, displayed in frames and vitrines, was no doubt unintentional..$^{51}$

The framing out of individuals and research institutions from the relevant epistemic community to address the why question of international criminal punishment concretely demonstrates the continuity of a political hegemony over international (criminal) law and its institutions - the notorious historical lineage that undermines the current rhetoric of 'humanity's law'. It has cast a shadow over the institutional record of the ICC in recent years, and remains a subject of intense critique also among state parties to the Rome Statute. If the objective is, in the words of Judith Butler, to expose the 'orchestrating design of the authority who sought to control the frame', $5^{2}$ these questions on the valued expertise and the interlocutors authorized to ask why? merit being posed.

\section{CONCLUSIONS}

The frames sketched out above all have their particular histories, with their repetitions, continuities, false continuities and, at times, ruptures. Both the frames themselves and the dominant and subservient positions the frames have in the discourse on international criminal justice are not the same today as they were at the time of the often-pictured birth moments in Nuremberg and Tokyo, for example. Historicizing the frames in more detail and ranking their respective positions and influences fall, however, beyond the scope of my impressionist comments on the chapters in the first part of this volume. What the frames in any case have in common is how the dominant intellectual parameters of the social sciences and law originated in the context of Western societies, anchored in a certain tradition and form of life, and implicitly in a religion with its particular moral conceptions. Despite the collapse of the greatest empires of the past and decolonization, there is a risk that knowledge and expertise remain obscured by 'the imbalances of power and the dynamics of othering and social exclusion in the present world order'. ${ }^{53}$

${ }^{11}$ On the museum, see Morrison, Criminology, 177-205.

52 J. Butler, Frames of War (London: Verso, 2010), 12.

53 K. Aas, 'Visions of Global Control' in M. Bosworth and C. Hoyle (eds.), What Is Criminology? (Oxford: Oxford University Press, 2011) 406, 413, with reference to B. Agozino, CounterColonial Criminology: A Critique of Imperialist Reason (London: Pluto Press, 2003);

C. Cunneen and J. Stubbs, 'Cultural Criminology and Engagement with Race, Gender and Post-colonial Identities' in J. Ferrell et al. (eds.), Cultural Criminology Unleashed (Portland: GlassHouse Press, 2004), 97; M. Bosworth and J. Flavin, Race, Gender and Punishment: From Colonialism to the War on Terror (Chapel Hill: Rutgers University Press, 2007). 
All the frames discussed above are susceptible to this risk. Moral communication on values sounds reasonable and necessary, but whose values does one communicate, based on what, who talks and who listens? When assumed universal values are set aside, as repeatedly happens for a multitude of reasons, whose voice carries furthest? The fight against impunity is an unquestionable goal at first sight, but who fights whom with what means, and whose impunity is always tolerated or obscured in the end? Furthermore, 'othering' drastically affects political considerations, guided by presumably rational calculations of what is feasible, not always exclusively in terms of money but also in terms of human lives and their living spaces. In these cases, too, lives and spaces do not have the same price for the 'international community' that decides. The most striking differences in what counts in the frames are not, then, between the international and the imagined domestic model, but between states and regions with regard to their political, economic and military weight.

These differences are well known, yet they merit emphasis here because they directly affect how the question 'Why punish perpetrators of mass atrocities?' is answered. In that sense, international criminal law and its current institutional practice represent one of the key mechanisms through which ideas about inferiority and subordination (political, social, economic, cultural and 'racial'54) are constructed and represented. Reflecting the filmmaker's techniques of framing and montage, international criminal justice as an intellectual and political project risks including the subordinated societies of the Global South solely on account of their criminality, leaving the societies themselves and their political agency definitively hors-champ.

The why word is out now, and that is a good thing. Outing the complex, defiant question 'why punish?' is a key achievement of the Hamburg symposium and this volume. International criminal law should not remain a sanctuary to which criminologists, sociologists, political scientists and others less inclined to the repetitive credos in law and legal institutions are denied access. Empirical studies flourish today, and so they should. Theories are critically tested, and trusted articles of faith are interrogated. The tensions this creates in the normative groundings of international criminal law are healthy. These intellectual confrontations may end up contributing to the maturing of the enchanted vision of international punishment. ${ }^{55}$ To be sure, one feels

54 I am writing 'racial' to flag the lack of any scientific or legal consensus on a definition of the concept, see, e.g., C. Lingaas, The Concept of Race in International Criminal Law (Abingdon: Routledge, forthcoming 2019).

55 On 'enchantment' as an intellectual position in international law, see I. Hurd, 'Enchanted and Disenchanted International Law’ (2016) 7 Global Policy 96. 
impotent reaching for frames that appear far too difficult to comprehend or act upon. Who could reform the UN Security Council or affect the global distribution of resources, in any case? Nevertheless, asking why beyond the obvious frames may affect the how, the what, and the who. Such frame breaks could - it is not prohibited to hope - engender change that ultimately contributes to the broadly shared and powerful objective of a world with less mass atrocity. 